Article

\title{
The Application of Photovoltaic Systems in Sacred Buildings for the Purpose of Electric Power Production: The Case Study of the Cathedral of St. Michael the Archangel in Belgrade
}

\author{
Budimir Sudimac ${ }^{1, *(1)}$, Aleksandra Ugrinović ${ }^{1}\left[\right.$ and Mišo Jurčević ${ }^{2}$ \\ 1 Department of Architectural Technology, the University of Belgrade's Faculty of Architecture, Bulevar kralja \\ Aleksandra 73/2, 11000 Belgrade, Serbia; aleksandra.ugrinovic@arh.bg.ac.rs \\ 2 LTEF- Laboratory for Thermodynamics and Energy Efficiency, Faculty of Electrical Engineering, Mechanical \\ Engineering and Naval Architecture, the University of Split, Ruđera Boškovića 32, 21000 Split, Croatia; \\ misjurce@fesb.hr \\ * Correspondence: sudimac@arh.bg.ac.rs
}

Received: 13 January 2020; Accepted: 7 February 2020; Published: 14 February 2020

check for updates

\begin{abstract}
In light of climate changes, technological development and the use of renewable energy sources are considered very important nowadays, both in newly designed structures and reconstructed historic buildings, resulting in the reduction in the commercial energy consumption and $\mathrm{CO}_{2}$ environmental emissions. This paper explores the possibilities of improving the energy efficiency of sacred heritage buildings by utilizing photovoltaic systems. As an exceptionally significant cultural good, the Cathedral of St. Michael the Archangel in Belgrade shall serve as a case study, with the aim of examining the methods of mounting photovoltaic (PV) panels, taking into account the fact that the authenticity and the aesthetic value of this cultural monument must remain intact. A comparative analysis of the two options for installing PV panels on the southwestern roof of the church was performed using simulations in PVgis and PVsist V6.84 software, with the aim of establishing the most efficient option in terms of power generation. The simulation results show that photovoltaic panels can produce 151,650 kWh (Option 1) and 150,894 kWh (Option 2) per year, while the required amount of energy is $42,726 \mathrm{kWh}$. The electricity produced exceeds the electricity requirements for the decorative lighting of the Cathedral Church, so it can be used for other purposes in the sacred complex.
\end{abstract}

Keywords: solar energy; photovoltaic systems; heritage structures; sacred architecture; the Cathedral of St. Michael the Archangel; Belgrade

\section{Introduction}

We stand to witness increasingly frequent natural disasters occurring around the world as a result of climate change. The European Union has recognized this global problem and passed the Energy Performance of Buildings Directive, as well as the standards for the use of renewable energy sources. The EU aims to produce 20\% of its energy from renewable sources by 2020 [1]. The EU encourages the use of renewable energy sources through various schemes parallel to promoting and raising awareness of their importance. The advantages of switching from conventional energy sources to renewable ones are the reduction in $\mathrm{CO}_{2}$ emissions, environment protection, and the reduction in utility-related costs. Using renewable energy sources is a necessity in the present day. The excessive exploitation of fossil fuels as natural resources, in addition to deforestation and wood burning, and consequent $\mathrm{CO}_{2}$ emissions, has resulted in global warming and the rise of sea levels, with adverse effects on all the living organisms on Earth. Environmental protection efforts and sustainability are becoming 
ever-greater priorities in local development policies and everyday life. In 1987, the United Nations issued the Brundtland Report titled "Our Common Future", which defines sustainable development as the "development that meets the needs of the present without compromising the ability of future generations to meet their own needs" [2] (p. 37). Sustainable energy sources are one such possibility, the use of which can result in energy sustainability.

The present paper explores the possibilities of using solar energy, proceeding to look at the strengths and weaknesses, as well as issues that may be raised during the adaptation and mounting of photovoltaic systems onto heritage churches with the aim of producing electric power. As is the case with structures of different uses, the reconstruction of sacred heritage buildings requires improvements in energy efficiency and ensuring energy sustainability by utilizing renewable energy sources, which is in line with the modern requirement to reduce $\mathrm{CO}_{2}$ emissions. The standards adhered to in the construction of these buildings are out of date due to the development of technologies and materials, nor are they aligned with the current regulations, thus a reworking is necessary. Historic architecture must be adapted to modern requirements, ensuring that in finding ways to achieve this, their historic, stylistic, and aesthetic uniqueness is preserved. The advantage of using solar energy, compared to other renewable sources, lies in the fact that the energy source in question is inexhaustible. In addition, the use of photovoltaic panel systems in sacred buildings is the most efficient because of the west-east orientation of churches along the longitudinal axis, which ensures ideal position for the collection of solar energy and thus for reaching full capacity of electric power production on the south-facing roof plane [3]. However, a problem is that photovoltaic panels could diminish the aesthetic value of a heritage church. No activities must be undertaken that would affect either the shape or the appearance of a cultural property [4]. The preservation of heritage churches is rarely based on environmental and, concomitantly, economic sustainability precisely due to the principles of protection and preservation of historical and stylistic authenticity. It is necessary to strike a balance and find a compromise between the preservation aspects and energy sustainability, as well as mitigating the effects of climate changes. Such examples from around the world indicate that it is possible to ensure a synergy of photovoltaic (PV) systems and abide by the regulations concerning heritage cultural monuments. The examples of practices from around the world can provide specific guidelines for mounting PV systems on heritage churches. PV panels must be independent of the building itself, mounted on the sub-structure that can be removed without any effects on the heritage building [5]. It is necessary to ensure the reversibility, i.e., reestablishing the condition of the structure in question prior to the intervention and installation of the photovoltaic systems. The elements of the system must not be visible from the outside or diminish in any way the aesthetic value of the protected building. For these reasons each protected structure must be approached individually, identifying the most adequate place for mounting PV panels in order not to detract from the appearance of the heritage sacred building and diminish its aesthetic and historic values. The modern methodology determining the degree of intervention on architectural heritage structures rests on a comprehensive scientific analysis of all the elements which must be taken into account when making the decision [6]. The approval of the competent authority (municipal, regional, or republic cultural heritage preservation institute) must be sought for all the interventions on protected cultural monuments. Reconstruction can be initiated only when the competent authority issues the technical protection measures and determines the type of intervention which can be undertaken on the structure. Although in 2012 the Government of the Republic of Serbia adopted the national strategy for the sustainable use of natural resources and goods [7], there are no standards for the application of systems of renewable energy sources in construction, and consequently in sacred architecture. As the church is one of the most influential social institutions, this fact should be made use of. The church can raise awareness of the importance of using renewable energy sources through education, and promote the idea of a healthy lifestyle and environmental pollution reduction.

Unlike Serbia, other countries do use photovoltaic systems in heritage churches. The Church of England has taken seriously the climate change that the entire world is facing and has made a contribution by joining the $\mathrm{CO}_{2}$ emission reduction project. The role of the Church of England is 
to educate people about the importance of switching to renewable energy sources with the aim of protecting the environment, i.e., the surroundings which have a direct impact on the quality of life and health of us all. Over 5500 churches in the United Kingdom have switched to renewable energy sources. As many as 150 PV panels were mounted on the Gloucester Cathedral in 2016 (Figure 1a). England aims to reduce $\mathrm{CO}_{2}$ emissions by $80 \%$ by 2050 [3]. Besides England, Germany has been putting in great efforts in using renewable energy sources, although the solar resources are less than $1000 \mathrm{kWh} / \mathrm{m}^{2}$ annually [1]. Figure $1 \mathrm{~b}$ shows the Herz-Jesu church in Plauen, Germany, where 80 PV panels with anti-reflective front glass and hidden fixtures are mounted on $160 \mathrm{~m}^{2}$ of the roof area [5]. One of the first major projects in integrating solar energy as a renewable energy source in a heritage structure is the reconstruction of the Reichstag in Berlin (Figure 2a) - a monument of worldwide importance. The reconstruction of this building has resulted in significant changes in its outward appearance. Although the Reichstag is a symbol of the German state, the reconstruction and introduction of renewable energy sources have turned it into a symbol of the European energy policy $[5,8]$. Unlike Germany, Italy has very good solar resources, ranging between $900 \mathrm{kWh} / \mathrm{m}^{2}$ and $1800 \mathrm{kWh} / \mathrm{m}^{2}$ [1]. PV panels are mounted on the roofs of the Vatican buildings (Figure 2b) in such a way as for this newly-established state to produce almost all of its electrical power from renewable energy sources, i.e., solar panels. The examples of implementations provided are one of the strongest arguments in favor of the claim that the construction of solar panels on protected buildings and cultural-historic areas does not detract from their appearance, but rather creates a new aesthetic experience. Depending on what the aims are, two approaches in mounting PV panels on heritage structures can be perceived. The first is for the elements of the PV system to be visible on the roof or façade of the structure and be visually dominant (as is the case with the Reichstag); the other approach—“camouflaging"—-makes use of the principle of minimal intervention in order to preserve the original appearance of a building (characteristic of protected churches) [5]. In Serbia, the use of systems of renewable energy sources must be included in the modern approaches to the protection of cultural goods, and standards must be set, as this is necessary due to excessive energy resource consumption.

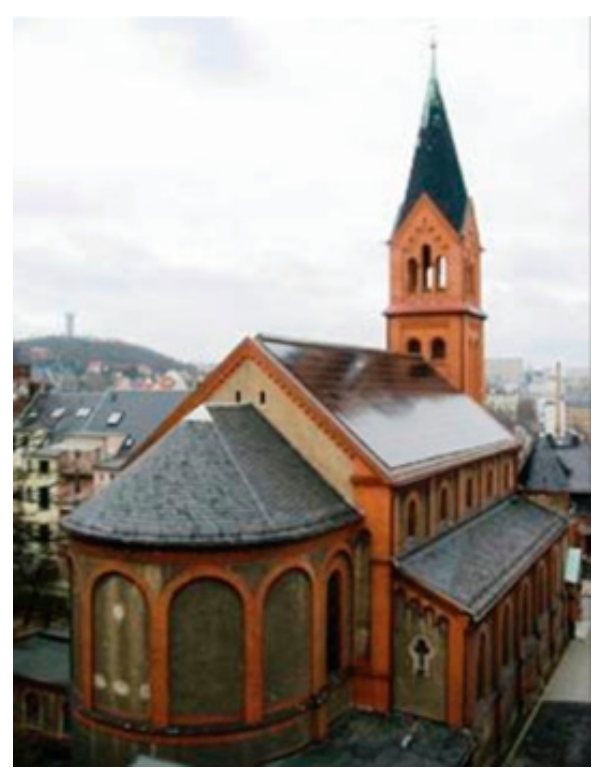

(a)

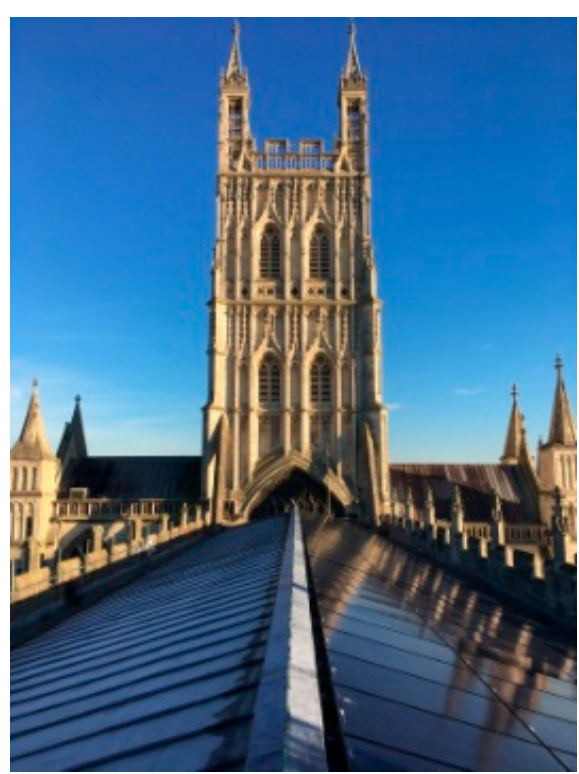

(b)

Figure 1. The Application of Photovoltaic Systems in Sacred Buildings: (a) The solar panels on the roof of the Gloucester Cathedral [9]; (b) Herz-Jesu church, Plauen (Germany): Installed photovoltaic system on the roof of the Lutheran Church in Saxony [5]. 


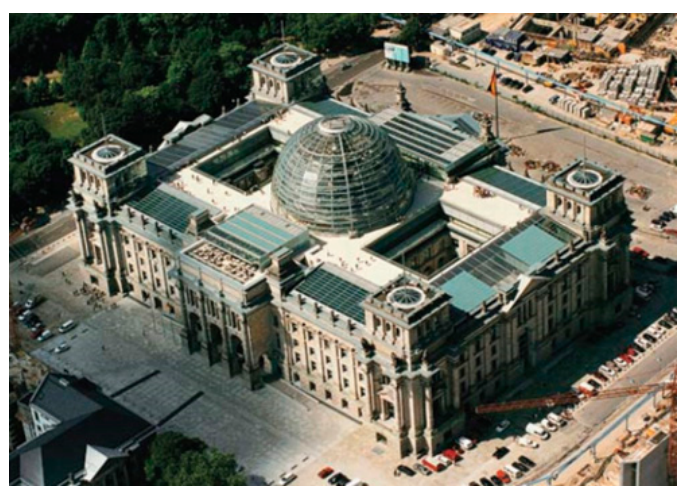

(a)

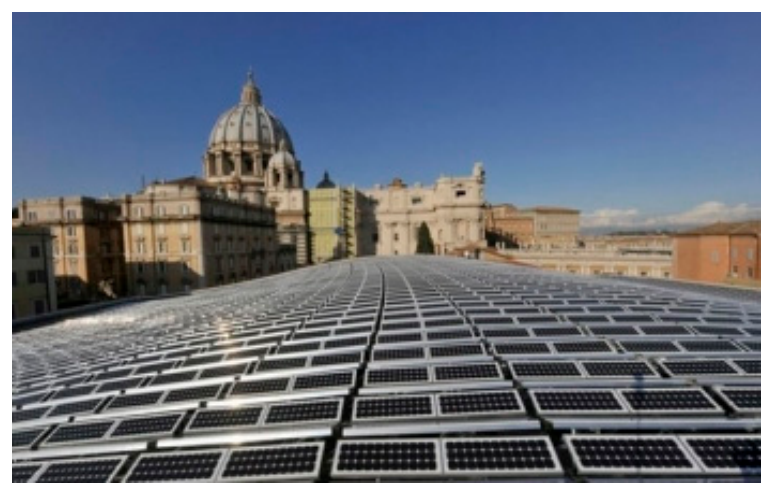

(b)

Figure 2. Solar panels on protected buildings and cultural-historic areas: (a) Protected heritage Reichstag building, Source: [5]; (b) Solar panels on the roof of the Nervi Hall in Vatican. Source: [10].

In order to explore the architectural and energy possibilities of using PV solar systems in the local Belgrade climate, a hypothetical analysis was carried out on the example of Belgrade Cathedral, an immovable cultural property of exceptional value. The methodology of the work is based on literature review, simulation of experimental models (Option 1 and Option 2) in PVgis and PVsist V6.84 software and comparative analysis of the obtained results. This study includes the analysis of the climatic characteristics of Belgrade, the analysis of existing electricity consumption in the illumination of Belgrade Cathedral, the possibility of installing PV modules on this church, the analysis of the amount of electricity obtained from renewable sources, and the assessment of $\mathrm{CO}_{2}$ emissions reductions.

To this date, no studies have been conducted on the use of PV panels on protected objects of sacred architecture. The contribution of this paper is to evaluate the efficiency of using photovoltaic solar systems in churches in Serbia to produce electricity based on European studies and good practice examples. The aim of this paper is to investigate the use of renewable energy systems, and thus raise public awareness in Serbia of the importance and possibilities of applying photovoltaic systems in sacred heritage buildings and reduce the consumption of commercial energy and $\mathrm{CO}_{2}$ environmental emissions, ensuring environmental and economic sustainability.

\section{The Energy Potential of Solar Radiation in Serbia}

The energy deficit problem in the world is solved by producing energy from renewable sources. They are the energy sources of the future. They are still not competitors to the conventional sources, and in many countries, including Serbia, there are no so-called Green Certificates, i.e., the legislation is not defined for the systems of renewable energy sources. However, their use will soon be necessary and mandatory.

Using the energy obtained from solar radiation is sufficient for meeting all energy demands in the world. One of the forms of using solar energy is the photovoltaic conversion, whereby photovoltaic receivers directly convert solar into electrical energy. The amount of electrical energy produced depends on the strength of solar radiation, the characteristics of the implemented technology, as well as the angle and position of the PV panel. Solar radiation varies in different parts of the world and depends on multiple factors: latitude, cloud cover, season, and time of day [11]. Serbia has the potential to use solar energy as the intensity of solar radiation is among the highest in Europe. The average intensity of solar radiation in the territory of the Republic of Serbia ranges from $1.1 \mathrm{kWh} / \mathrm{m}^{2} / \mathrm{per}$ day in the north up to $1.7 \mathrm{kWh} / \mathrm{m}^{2}$ per day in the south (in January), and from 5.9 up to $6.6 \mathrm{kWh} /{ }^{2}$ per day (in July). Annually, the average value of the energy of global radiation for the territory of the Republic of Serbia ranges from $1200 \mathrm{kWh} / \mathrm{m}^{2} /$ per year in the north-west of Serbia, up to $1550 \mathrm{kWh} / \mathrm{m}^{2} /$ per year in the south-east of Serbia, while in the central area it stands at around $1400 \mathrm{kWh} / \mathrm{m}^{2} /$ per year $[11,12]$. The map provided below shows the values of solar radiation in Serbia (Figure $3 a, b)$. The fact demonstrating 
the importance and efficiency of use of solar energy in Serbia is that the energy emitted by the sun annually per $1 \mathrm{~m}^{2}$ of a house roof corresponds to the energy obtained by burning $130 \mathrm{~L}$ of oil [12].

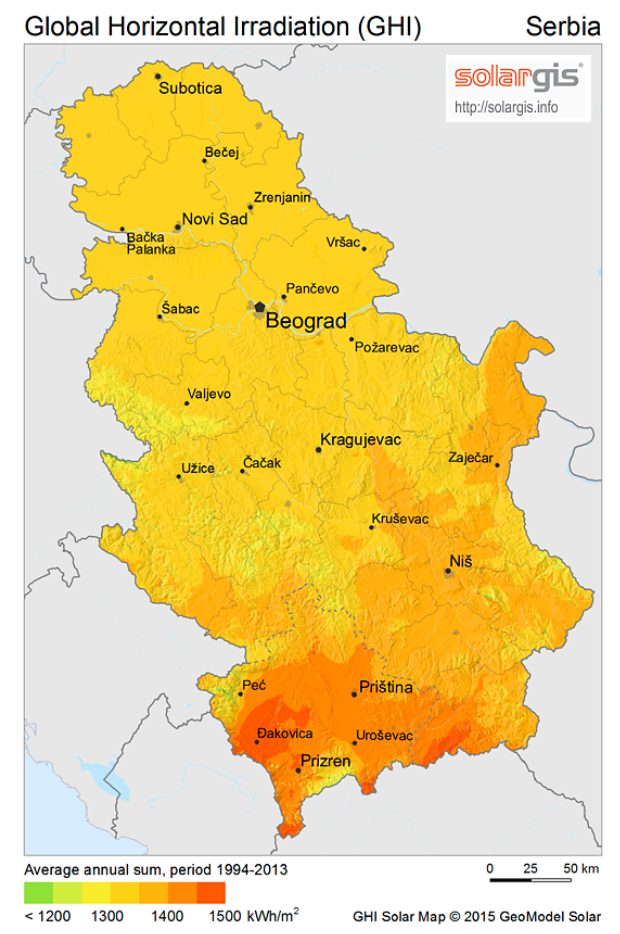

(a)

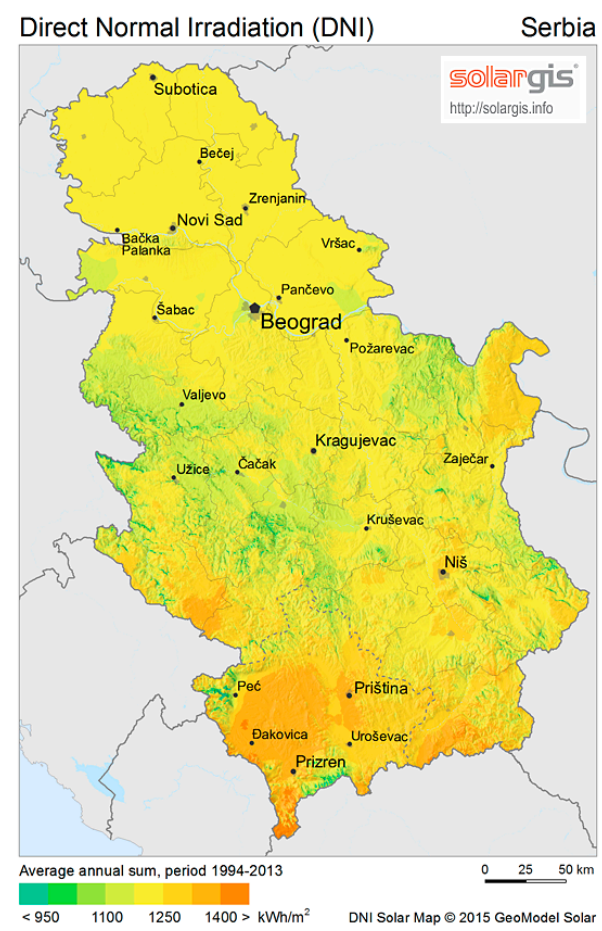

(b)

Figure 3. Annual solar radiation in Serbia in $\mathrm{kWh} / \mathrm{m}^{2}$ : (a) Global Horizontal Irradiation (GHI); (b) Direct Normal Irradiation (DNI) [13].

\section{The Photovoltaic Conversion of Solar Energy into Electric Power}

Photovoltaic systems (BIPV: Building-integrated photovoltaic systems) comprise several components. The PV cells are the main component of a photovoltaic system, and they form arrays and the panel. The basic function of the PV cell is to convert solar light into electrical energy. How much energy is produced depends on the number of cells in the panel. There are One-diode and Two-diode PV modules. Vincenzo F. et al. performed a comparative analysis of their efficacy $[14,15]$. The energy performance of one PV panel usually ranges between 180 and $250 \mathrm{~W}$ [14]. In addition to the PV panel, it is necessary to have the elements of the substructure in the form of prefabricated steel structures that the panel is mounted on, then the devices that convert the direct current to alternating, meters, and energy storage devices—the so-called batteries $[3,16]$. There are two kinds of panels in the market: those with monocrystalline and polycrystalline structure (Figure 4a1,a2). The difference between monocrystalline and polycrystalline cells lies in the fact that monocrystalline cells consist of a smaller number of big crystals, and therefore have a more ordered structure -and greater efficiency than the polycrystalline ones, which consist of a greater number of smaller crystal structures, and are less ordered. The efficiency of monocrystalline cells is the highest in the market at the moment, and stands at around $17 \%$ to $22 \%$, while the polycrystalline cells stand at around $11 \%$ to $17 \%$ [17]. The efficiency depends on the material used to make PV panels. Nowadays the technology of manufacturing solar cells is based mainly on silicon. Highest-efficiency modules need to be made from materials with the energy barrier ranging from 1.4 to $1.6 \mathrm{eV}$ [12]. These cells are multi-layered, and inside them the materials are stacked in layers such that the light first hits the higher-energy-barrier material. In this way, a greater portion of the solar spectrum is used, which increases the efficiency of the panel. The module dimensions depend on the number of cells in them, and are mostly standardized. The most 
frequent number of cells per module is 48,60 , and 72 . In a single panel group with the same number of cells, panel strength depends exclusively on cell efficiency, and not on their dimensions [12].
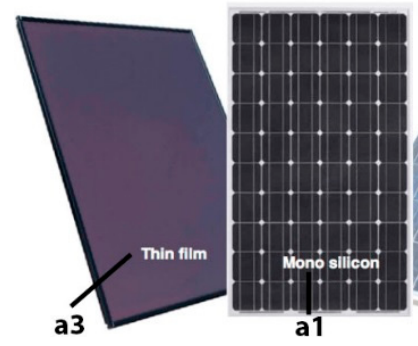

(a)

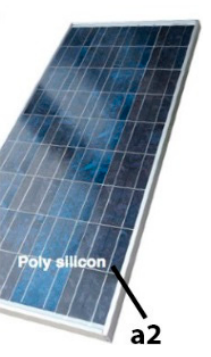

a

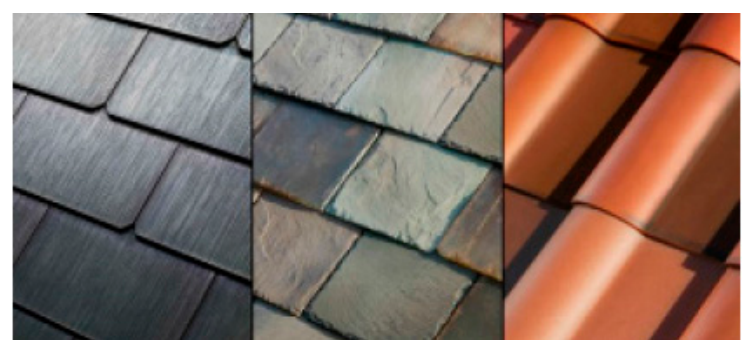

(b)

Figure 4. Types of PV panels: (a) Thin-film, monocrystalline and polycrystalline PV panel [18]; (b) The possibilities of integrating PV cells in the roof coating [3].

In addition to monocrystalline and polycrystalline silicon cells, there are also thin-film solar cells [12]. Thin-film solar cells (Figure 4a3) are placed directly on the glass, stainless steel, or polymer base. Their efficiency is considerably less than monocrystalline and polycrystalline cells, and stands on average at $6 \%$ to $11 \%[1,12]$.

Owing to technological development, PC cell performance constantly improves, both in terms of efficiency and the color and method of integration, which depends on the purpose and appearance of a building [16]. Therefore, there are products-PV panels-which are adapted for the use on historic structures during reconstruction with the aim of preserving their appearance, and are imitate the traditional materials used. These technologies can be integrated into the roof cover (Figure $4 \mathrm{~b}$ ). Slate, wood shingles, or tiles are set in the same manner, by overlapping, as are traditional roof covers. Furthermore, the PV panel color can be made in the hue of the cover it is set on [19-21].

\section{The Cathedral of St. Michael the Archangel in Belgrade as a Cultural Good of Exceptional Value}

The Belgrade Cathedral (Figure 5a) is located at the corner of Kralja Petra and Kneza Sime Markovića streets (Figure $5 b$ ) and is part of the protected cultural-historic ensemble of Kosančićev venac. The present-day church was erected on the location of the Church of St. Michael the Archangel, which had been destroyed and reconstructed many times in its history. The new cathedral, in its present-day appearance, was built at the order of Miloš Obrenović on the location of the old church. The construction of the church began on April 28th, 1837, and was completed eight years later, on November 21st, 1845. The Belgrade Cathedral is the second oldest church in Belgrade, after the Church of St. Peter and Paul in Topčider (built between 1832 and 1834) [22]. Due to its location, situated as it is on elevated ground, it was visible from all sides, and is still dominant in the skyline of Kosančićev venac, and is a symbol of Belgrade, alongside the Temple of Saint Sava.

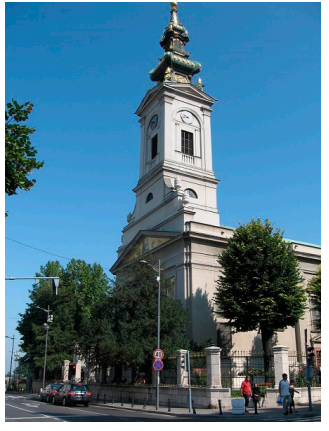

(a)

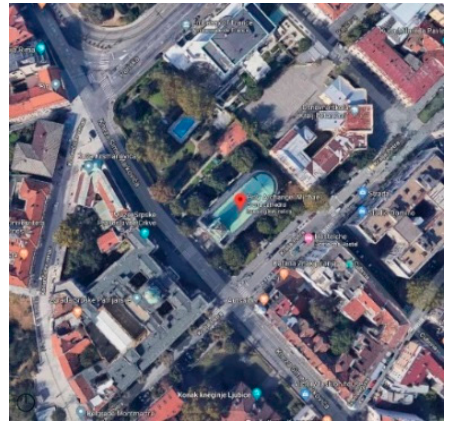

(b)

Figure 5. (a) The Belgrade Cathedral [23]; (b) The immediate surroundings (Google maps). 
The Belgrade Cathedral is a single-nave building, with the longitudinal base with the altar apse in the east, and the narthex and bell tower in the west. The spatial organization includes the narthex, naos, and altar space going from west to east (Figure 6a). The church entrance is located in the west façade, which stands out in terms of how representative it is. Based on the architectural elements and configuration, it can be concluded that St. Michael's Cathedral was modelled after the Neoclassical churches with baroque-style bell towers constructed in this period in Austria-Hungary (Figure 6b). Churches of this type were built very frequently in Serbia during the reign of Miloš Obrenović [22].

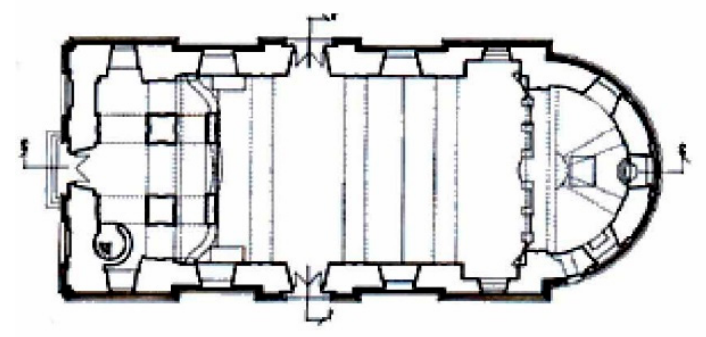

(a)

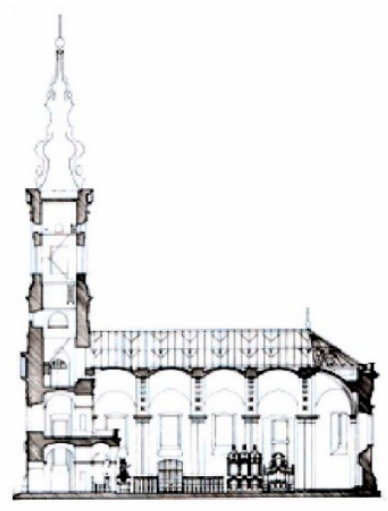

(b)

Figure 6. (a) The base of the Belgrade Cathedral; (b) The cross-section of the Belgrade Cathedral [24].

The Belgrade Cathedral stands as a testimonial of the life of the Serbian people in the first half of the $19^{\text {th }}$ century and the formation of the Principality of Serbia. It was declared a cultural good of exceptional significance in 1979 [22]. According to the law on cultural goods, cultural goods are designated as exceptionally significant if they are important in the social, historical, and cultural development of the nation, or are testimonials of historical events and persons, or represent rare examples of the creative output of the day, or have had a great impact on the development of the society, culture, technology, and science, or have an exceptional aesthetic or artistic value [25]. All structures, as well as urban, rural, and ambient ensembles which analyses indicate as possessing monumental features of public interest are placed under the protection of the state in a separate legal decision, and from that moment onwards special measures are implemented relating to them as prescribed by the law on the protection of cultural goods, irrespective of whether the cultural good in question is privately or publicly owned [6]. This means that no intervention can be undertaken on the cultural monument in question without the approval of the competent institution, because otherwise interventions could detract from its appearance. This problem occurs in mounting photovoltaic systems in heritage sacred buildings, when a suitable location and position need to be identified for PV panels in order for them to be as efficient as possible in the production of electrical energy without being visible in the church facade [19].

Illuminating the Belgrade Cathedral by means of conventional electrical energy sources is very expensive and has a negative effect on the environment. Illumination is provided by high-pressure sodium lights of varying installed power. It is highly light-efficient and has a limited radiation spectrum, reaching highest levels in the yellow-orange band. A favorable orientation with respect to cardinal points, the possibility of mounting PV panels on the building roof, the $30^{\circ}$ tilt angle of the roof plane, as well as a sufficient roof surface area were the reasons for selecting this building as the experimental environment. The building is south-west facing. Observations at various times of day and year revealed that no shadows were cast by surrounding structures, and that therefore there was no drop in module efficiency. Implementing this research study would improve the voltage-related situation in the city center and disburden the electricity distribution grid to an extent. 


\section{Materials and Methods}

\subsection{Analysis of Power Consumption for Illuminating the Belgrade Cathedral of St. Michael the Archangel}

This research is aimed at finding possible methods of reducing the consumption of conventional energy sources for the purpose of providing public lighting and illumination at the Belgrade Cathedral of St. Michael the Archangel. The determination of solar potential at the target location (N 44.818, E 20.452) was of prime importance for all the calculations presented here, and it was performed in the following ways:

- by means of numerical data for horizontal irradiation in Belgrade, Serbia;

- using the free online version of PVgis (Figure 7) and PVsyst V6.84 software that utilizes satellite data for quantifying solar potential.

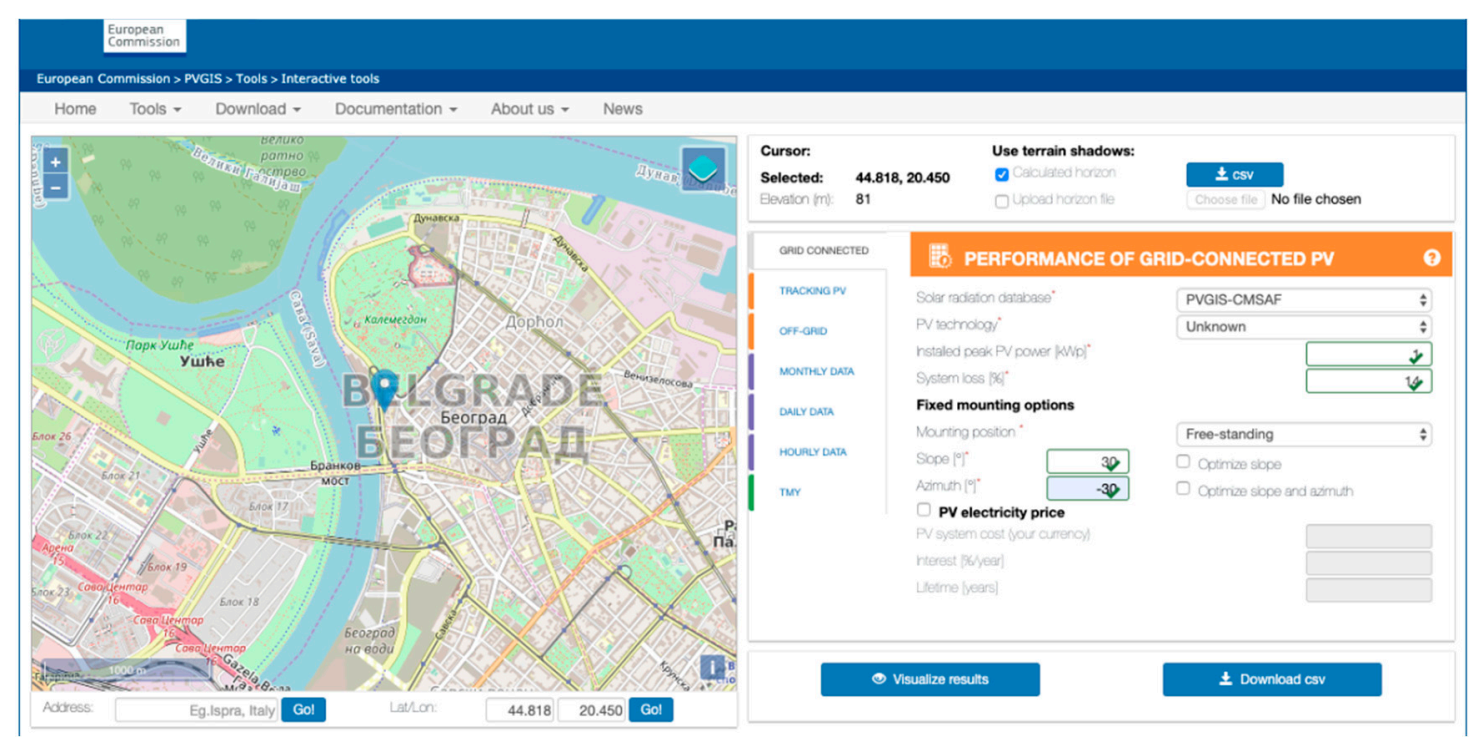

Figure 7. PVgis software interface. Source: authors.

The mean daily sum of energy produced by the global solar radiation on the horizontal surface in Belgrade equals $3.96 \mathrm{kWh} / \mathrm{m}^{2}$, while the total annual insolation stands at $1446.80 \mathrm{kWh} / \mathrm{m}^{2}$. Diffuse component of the annual insolation is $451.97 \mathrm{kWh} / \mathrm{m}^{2}$, while the direct annual component of insolation is $997.207 \mathrm{kWh} / \mathrm{m}^{2}$. The highest mean value of insolation is recorded in June- $6.75 \mathrm{kWh} / \mathrm{m}^{2}$, while the lowest is reserved for December, when it falls to $1.15 \mathrm{kWh} / \mathrm{m}^{2}$. The mean annual irradiation at the angle of $30^{\circ}$ amounts to $168.16 \mathrm{~W} / \mathrm{m}^{2}$.

According to the Republic Hydrometeorological Service of Serbia, the total length of daylight for Belgrade is $4464.83 \mathrm{~h}$ a year [26-28]. The shortest monthly period of daylight is recorded in December, reaching $270.56 \mathrm{~h}$, while the longest one is in July, with $473.42 \mathrm{~h}$. According to the current calendar of switching the public lighting on and off in the City of Belgrade, the total working hours of the public lighting in Belgrade stand at $4148.23 \mathrm{~h}$ a year. The shortest working hours of public lighting are in June-222.30 h, while the number peaks in December with $467.45 \mathrm{~h}$. The presented data on the working hours of lighting are in direct correlation with the length of daylight period in Belgrade.

The average time available for the production of electric power- $T_{P V}$, in the three summer months (June, July and August) in Serbia stands at around $6.6 \mathrm{~h}$. During three winter months (December, January and February) it amounts to only about $1.06 \mathrm{~h}$, resulting in the following: $1.06 \mathrm{~h} \leq T_{P V} \leq 6.6 \mathrm{~h}$. The total annual number of insolation hours in Serbia equals [11,29]:

$$
\mathrm{Ta}=\sum_{n=1}^{12} E i / P p v=1.442,8 h
$$


The calculation was performed taking into consideration the consumption of electric power for the purpose of public lighting according to the data collected by the Public Utility Company "Public Lighting" Belgrade. The number of street lights in the surveyed area is 15, and they vary in the installed capacity and type (Table 1).

Table 1. Overview of the existing decorative lighting and electric power needs for the operation of public lighting in the Belgrade Cathedral (Public Utility Company “Public Lighting” Belgrade).

\begin{tabular}{cccccc}
\hline Lamp Mark & Source Type & Lamp Type & Pieces & Lamp Power in kW & Total \\
\hline RT3 NB/150/83 & $\begin{array}{c}\text { High-pressure } \\
\text { sodium-vapor lamp } \\
\text { RT4 }\end{array}$ & SON-T 150 W & 2 & 0.15 & 0.3 \\
N/1000/1103 & $\begin{array}{c}\text { Sodium-pressure } \\
\text { High-pressure }\end{array}$ & SON-T 1000 W & 2 & 1 & 2 \\
RT3 NB/400/71 & $\begin{array}{c}\text { SOdium-vapor lamp } \\
\text { High-pressure }\end{array}$ & SON-T 1000 W & 6 & 0.4 & 2 \\
RT4 & $\begin{array}{c}\text { Sodium-vapor lamp } \\
\text { TOTAL }\end{array}$ & $\mathbf{1 5}$ & $\mathbf{2 . 5 5}$ & 6 \\
\hline
\end{tabular}

The total installed capacity for the purpose of Belgrade Cathedral's public lighting is $10.30 \mathrm{~kW}$ (Table 1). The required amount of electric power for operating such kind of lighting, depending on the public lighting working hours, amounts to $42,726.77 \mathrm{kWh}$ a year. The greatest consumption of electric power is recorded in December, with $4814.74 \mathrm{kWh}$, while it falls in June to $2289.69 \mathrm{kWh}$. The total amount of energy needed for this purpose comes from conventional energy sources.

According to the current tariff system, the price of electric power is RSD 6.8 per $\mathrm{kWh}$, so the cost of the total annual consumption of electric power for lighting the Belgrade Cathedral reaches (Table 2) $42,726.77 \mathrm{kWh} \times \mathrm{RSD} 6.8 / \mathrm{kWh}=\mathrm{RSD} 290,542.03$ or EUR2,343.08. The existing lamps are modern, of excellent photometric characteristics and high level of mechanical and electric protection, with long exploitation life.

Table 2. Overview of lighting and electric power consumption of the existing public lighting system in the Belgrade Cathedral (Public Utility Company “Public Lighting” Belgrade).

\begin{tabular}{|c|c|c|c|c|c|}
\hline & \multicolumn{3}{|c|}{$\begin{array}{l}\text { Sodium-Vapor } \\
\text { Lamps }\end{array}$} & \multirow[b]{2}{*}{$\begin{array}{c}\text { Installed } \\
\text { Capacity in } \\
\text { kW }\end{array}$} & \multirow[b]{2}{*}{$\begin{array}{c}\text { Total } \\
\text { Consumption Per } \\
\text { Month in kW }\end{array}$} \\
\hline & $\begin{array}{l}\text { No. of } \\
\text { Working } \\
\text { Hours }\end{array}$ & $\begin{array}{l}\text { No. of } \\
\text { Days }\end{array}$ & $\begin{array}{l}\text { No. of } \\
\text { Lamps }\end{array}$ & & \\
\hline January & 452 & 31 & 15 & 10.30 & 4655.60 \\
\hline February & 385.15 & 28 & 15 & 10.30 & 3967.05 \\
\hline March & 364.15 & 31 & 15 & 10.30 & 3750.75 \\
\hline April & 310.13 & 30 & 15 & 10.30 & 3194.34 \\
\hline May & 271.15 & 31 & 15 & 10.30 & 2792.85 \\
\hline Jun & 222.3 & 30 & 15 & 10.30 & 2289.69 \\
\hline July & 248 & 31 & 15 & 10.30 & 2554.40 \\
\hline August & 286.45 & 31 & 15 & 10.30 & 2950.44 \\
\hline September & 327 & 30 & 15 & 10.30 & 3368.10 \\
\hline October & 392.45 & 31 & 15 & 10.30 & 4042.24 \\
\hline November & 422 & 30 & 15 & 10.30 & 4346.60 \\
\hline December & 467.45 & 31 & 15 & 10.30 & 4814.74 \\
\hline Total & 4148.23 & 365 & 180 & 123.6 & $42,726.77$ \\
\hline
\end{tabular}

\section{2. $\mathrm{CO}_{2}$ Emission}

The current data for Serbia show that the production of $1 \mathrm{kWh}$ of electric power from conventional energy sources releases $842 \mathrm{~g}$ of $\mathrm{CO}_{2}$ to the atmosphere. The analysis of the input data shows that the 
total $\mathrm{CO}_{2}$ emission is $35.98 \mathrm{t}$ a year (Table 3). The production of electric power from the renewable energy sources releases no $\mathrm{CO}_{2}$ to the atmosphere and does not pollute the environment.

Table 3. Overview of $\mathrm{CO}_{2}$ emission of the existing lighting by months (Public Utility Company "Public Lighting" Belgrade).

\begin{tabular}{ccccc}
\hline & $\begin{array}{c}\text { No. of } \\
\text { Working } \\
\text { Hours }\end{array}$ & $\begin{array}{c}\text { Total } \\
\text { Consumption Per } \\
\text { Month in kW }\end{array}$ & $\mathbf{C O}_{\mathbf{2}}$ Emission in $\mathbf{t}$ & $\begin{array}{c}\text { Total } \mathbf{C O}_{\mathbf{2}} \\
\text { Emission Per } \\
\text { Month in }\end{array}$ \\
\hline January & 452 & 4655.60 & 0.000842 & 3.92 \\
February & 385.15 & 3967.05 & 0.000842 & 3.34 \\
March & 364.15 & 3750.75 & 0.000842 & 3.16 \\
April & 310.13 & 3194.34 & 0.000842 & 2.69 \\
May & 271.15 & 2792.85 & 0.000842 & 2.35 \\
Jun & 222.3 & 2289.69 & 0.000842 & 1.93 \\
July & 248 & 2554.40 & 0.000842 & 2.15 \\
August & 286.45 & 2950.44 & 0.000842 & 2.48 \\
September & 327 & 3368.10 & 0.000842 & 2.84 \\
October & 392.45 & 4042.24 & 0.000842 & 3.40 \\
November & 422 & 4346.60 & 0.000842 & 3.66 \\
December & 467.45 & 4814.74 & 0.000842 & 4.05 \\
Total & $4 \mathbf{4 1 4 8 . 2 3}$ & $\mathbf{4 2 , 7 2 6 . 7 7}$ & $\mathbf{0 . 0 1 0 1 0 4}$ & $\mathbf{3 5 . 9 8}$ \\
\hline
\end{tabular}

\subsection{Belgrade Cathedral—PV Panels Installation Possibilities}

The possibility of installing photovoltaic panels on sacred buildings depends on the architectural characteristics of the church itself. The main challenge in implementing the PV module system in protected areas is that the solar panels must be exposed to the sun, be efficient, and be visible as a result. PV panels on architectural structures significantly affect their appearance, thus demanding striking a balance between heritage preservation and public utility in applying PV modules. Applying PV modules on sacred buildings is possible only if the following conditions are met:

- their use does not result in the loss of the particular interest of protection;

- the visual impact of the installed equipment is slight;

- that mounting and installing the equipment does not damage the historic material;

- the installed equipment does not produce long-term effects on the structure in question.

When it comes to sacred buildings, photovoltaic systems can be installed on the roof of the building or PV cells can be integrated with window panes on the south side. Possibilities for setting up PV systems on sacral objects are given in Figure 8.

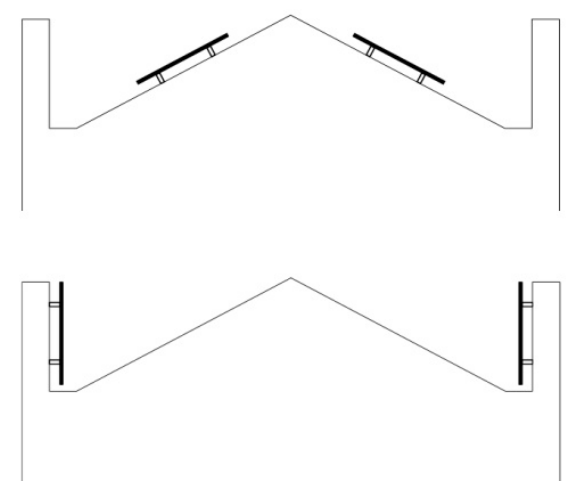

(a)

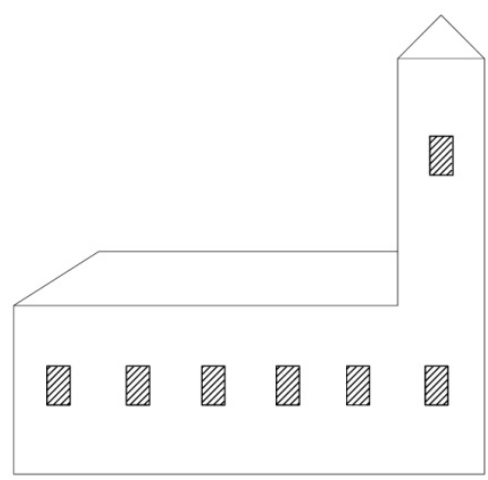

(b)

Figure 8. Possibilities of placing PV systems on sacral objects: (a) Placing PV modules over the substructure on the roof and building; (b) Integration of PV cells into window glazing. (authors). 
The artistic value of the stained-glass windows of the Cathedral of St. Michael the Archangel in Belgrade restricts the integration of PV cells into the window panes. For that reason, the most convenient option in this case is to mount a photovoltaic system on the south-western roof plane, since the position and the orientation of the church permits it. In the close vicinity of the Cathedral, there is no tall greenery or high multistoried structures that would cast a shadow on the south-western roof. Another convenience is that the surface of the roof cannot be seen from the ground. In order to preserve the original view of the church, it is possible to design the panels in the color of the base they are mounted on. This is also recommended by the authors of the article "Acceptance of Building Integrated Photovoltaic (BIPV) in Heritage Building and Landscape: Potentials, Barrier and Assessment Criteria", and the faster development of technologies and materials enables this [20]. In this particular case the color of choice would be grey/green (Figure 9) so that the PV panels be in conformity with the existing verdigris coating of the copper-sheet roofing.

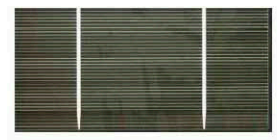

Grey/Brown

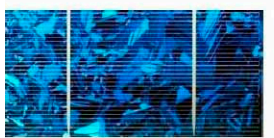

Blue

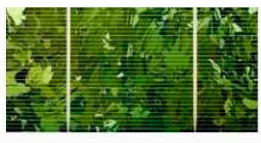

Green

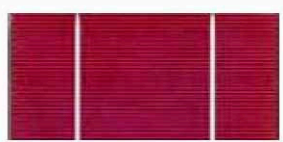

Red

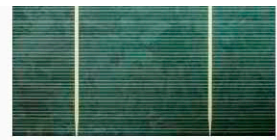

Grey/Green

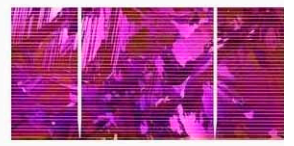

Purple

Figure 9. Polycrystalline panels color palette [30].

In the case of the Belgrade Cathedral, PV panels are to be mounted on the south-western roof plane, so that the inclination of the panels corresponds to the inclination of the roof itself $\left(30^{\circ}\right.$ angle, Figure 10a) or the PV panels inclination angle can be determined irrespective of the roof sloping degree (Figure 10b), by employing the sub-structure inclined at the desired angle. The comparative analysis of the two options for mounting PV panels (Figure 10a,b) presented in the next section of this paper, will show which one is more efficient in terms of energy production. Different inclination of PV panels affects their efficiency and consequently the total monthly and annual rates of power production.

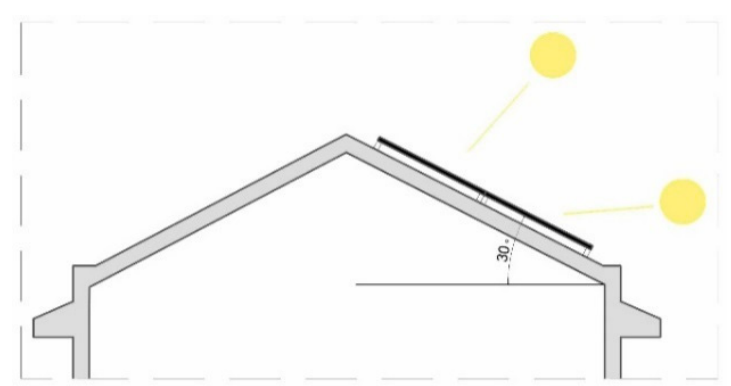

(a)

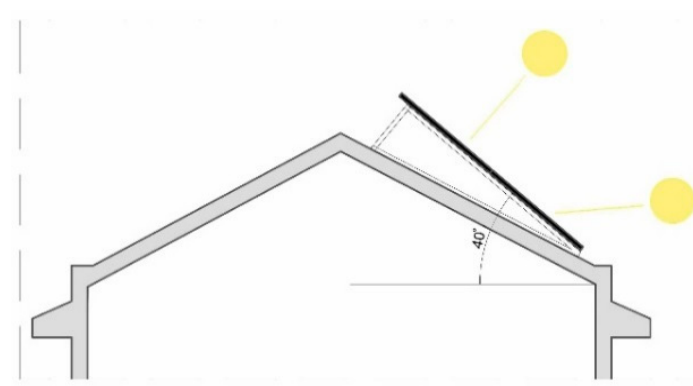

(b)

Figure 10. PV panel installation on the Belgrade Cathedral's roof: (a) option 1; (b) option 2. (authors).

\section{Results: Analyzing Options for PV Panels Installation}

For the purpose of comparing both monthly and annual production of power to be used for the illumination of the Belgrade Cathedral by the installed photovoltaic modules, two options were analyzed.

The roof area for installing PV modules is set at $212.50 \mathrm{~m}^{2}$, with the size of $25 \mathrm{~m} \times 8.5 \mathrm{~m}$. For the purpose of this research, a polychristal PV module is used, a $165 \times 99 \mathrm{~cm}$ panel with the total surface area of $1.63 \mathrm{~m}^{2}$. The optimum horizontal positioning of panels enables the installation of 125 panels. 
The total installed power of the panels is $133.58 \mathrm{~kW}$. Belgrade Cathedral is positioned at $30^{\circ}$ southwest. It is planned that the solar panels be installed on the roof, which has the most beneficial azimuth angle.

- Option 1-PV modules on the roof, non-transparent, polycrystalline, $30^{\circ}$ inclination.

- Option 2-PV modules on the roof, non-transparent, polycrystalline, $40^{\circ}$ inclination.

The fact that PV panels produce direct current output and that they are connected to the power network via the alternating current system commands the use of inverters that transform direct current into the alternating current. This particular project would require seven $20 \mathrm{~kW}$ inverters and two 10 $\mathrm{kW}$ inverters.

Such supply systems are designed to meet the electric power needs in summer months almost exclusively from PV panels. In spite of the load that considerably varies throughout the year, the suggested system should be flexible in order to enable the greater consumption of electric power in those days when it is needed. During summer months, the PV system power supply is sufficient to meet the total power consumption.

The analysis of the necessary number of PV modules for the steady operation of the public lighting of the Belgrade Cathedral, performed in PVsyst V6.84 software, produced the following results:

Option 1

Photovoltaic modules of the total surface area of $212.50 \mathrm{~m}^{2}$, i.e., 125 panels of the total installed power of $133.58 \mathrm{~kW}$, produce minimum $3812 \mathrm{kWh}$ of power per month in December and maximum $20,030 \mathrm{kWh}$ in July. Total annual power production in Option 1 is set at 151,650 kWh. The amount of power needed for illumination of the Belgrade Cathedral is $42,726.77 \mathrm{kWh}$. This option therefore satisfies the needs for electric power for the illumination of the total area of the Cathedral (Figure 11).

This section may be divided by subheadings. It should provide a concise and precise description of the experimental results, their interpretation as well as the experimental conclusions that can be drawn.
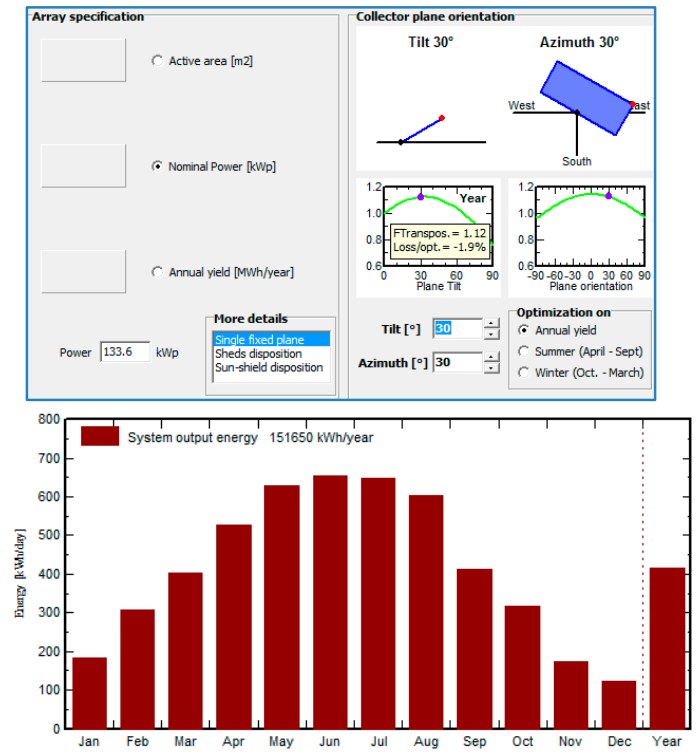

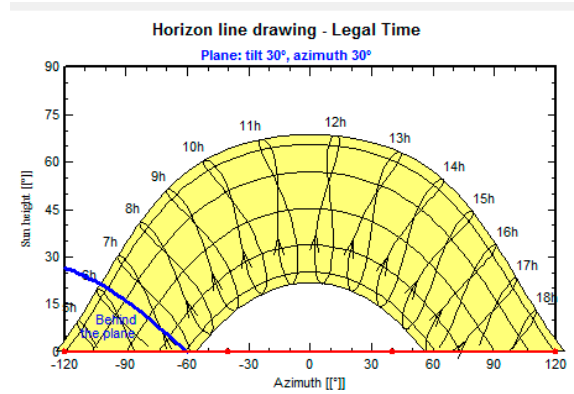

No Azimuth Height[0]

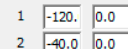

$2 \longdiv { - 4 0 . 0 } \longdiv { 0 . 0 }$

$3 \longdiv { 4 0 . 0 } \sqrt { 0 . 0 }$

\begin{tabular}{|c|c|c|c|c|}
\hline & $\begin{array}{c}\text { Gl. horiz. } \\
\text { kWh/m2.day }\end{array}$ & $\begin{array}{c}\text { Coll. Plane } \\
\text { kWh/m2.day }\end{array}$ & $\begin{array}{c}\text { System output } \\
\text { kWh/day }\end{array}$ & $\begin{array}{c}\text { System output } \\
\mathrm{kWh}\end{array}$ \\
\hline Jan. & 1.06 & 1.64 & 184.4 & 5715 \\
Feb. & 2.01 & 2.74 & 308.1 & 8627 \\
Mar. & 2.90 & 3.59 & 402.5 & 12478 \\
Apr. & 4.21 & 4.69 & 526.7 & 15800 \\
May & 5.46 & 5.60 & 628.3 & 19478 \\
June & 5.90 & 5.81 & 652.6 & 19578 \\
July & 5.76 & 5.76 & 646.1 & 20030 \\
Aug. & 5.00 & 5.38 & 604.2 & 18731 \\
Sep. & 3.20 & 3.68 & 413.0 & 12389 \\
Oct. & 2.18 & 2.81 & 315.9 & 9794 \\
Nov. & 1.12 & 1.55 & 173.9 & 5218 \\
Dec. & 0.73 & 1.10 & 123.0 & 3812 \\
\hline Year & 3.30 & 3.70 & 415.5 & 151650 \\
\hline
\end{tabular}

Figure 11. Overview of calculations in PVsyst V6.84 for Option 1.

Option 2

Photovoltaic modules with the total surface area of $212.50 \mathrm{~m}^{2}$, i.e., 125 panels of the total installed power of $133.58 \mathrm{~kW}$, produce minimum $4076 \mathrm{kWh}$ of power per month in December, and up to maximum 19,271 kWh in July. Total annual power production in Option 2 amounts to 150,894 kWh. The amount of power needed for illumination of the Belgrade Cathedral is $42,726.77 \mathrm{kWh}$ (Figure 12). 

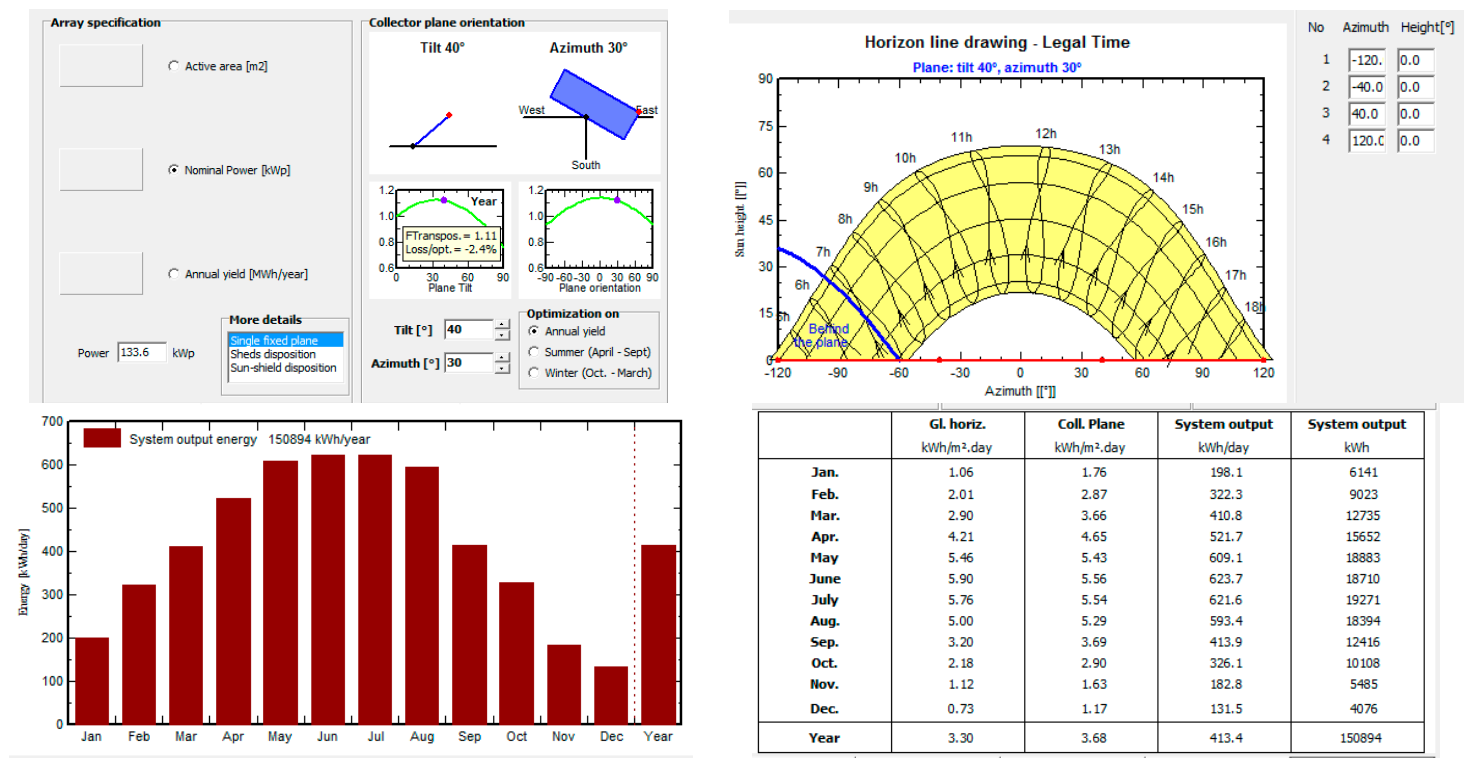

\begin{tabular}{|c|c|c|c|c|}
\hline & $\begin{array}{c}\text { Gl. horiz. } \\
\text { kWh/m2.day }\end{array}$ & $\begin{array}{c}\text { Coll. Plane } \\
\text { kWh/m2.day }\end{array}$ & $\begin{array}{c}\text { System output } \\
\text { kWh/day }\end{array}$ & $\begin{array}{c}\text { System output } \\
\text { kWh }\end{array}$ \\
\hline Jan. & 1.06 & 1.76 & 198.1 & 6141 \\
Feb. & 2.01 & 2.87 & 322.3 & 9023 \\
Mar. & 2.90 & 3.66 & 410.8 & 12735 \\
Apr. & 4.21 & 4.65 & 521.7 & 15652 \\
May & 5.46 & 5.43 & 609.1 & 18883 \\
June & 5.90 & 5.56 & 623.7 & 18710 \\
July & 5.76 & 5.54 & 621.6 & 19271 \\
Aug. & 5.00 & 5.29 & 593.4 & 13394 \\
Sep. & 3.20 & 3.69 & 413.9 & 12416 \\
Oct. & 2.18 & 2.90 & 326.1 & 10108 \\
Nov. & 1.12 & 1.63 & 182.8 & 5485 \\
Dec. & 0.73 & 1.17 & 131.5 & 4076 \\
\hline Year & 3.30 & 3.68 & 413.4 & 150894 \\
\hline
\end{tabular}

Figure 12. Overview of calculations in PVsyst V6.84 for Option 2.

\section{Comparative Analysis of Results}

Annually, the installed photovoltaic panels can produce 151,650 kWh of power (Option 1) or 150,894 kWh (Option 2), so the analyzed solutions satisfy the total annual demand for electric power and decorative illumination of the Belgrade Cathedral. The simulation results show that more electricity is produced when the panels are placed at a 30-degree incline, which corresponds to the slope of the roof plane of the St. Michael's Cathedral church (Figure 13a,b).

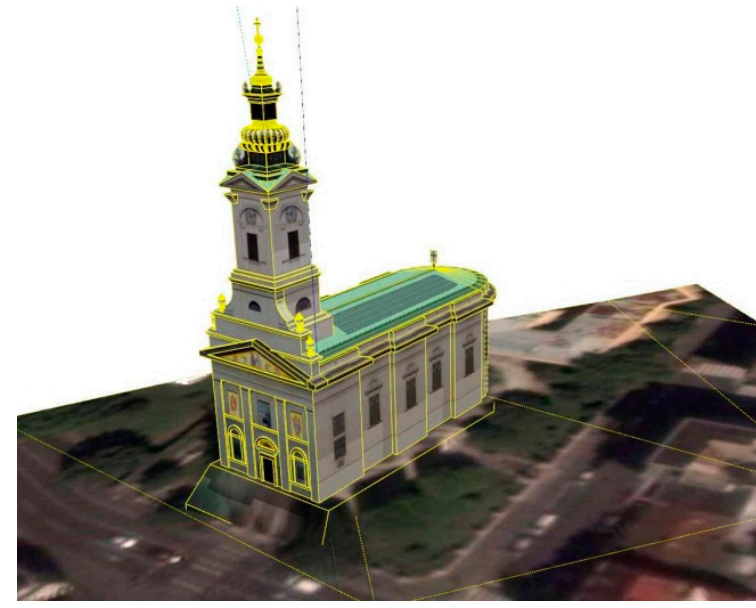

(a)

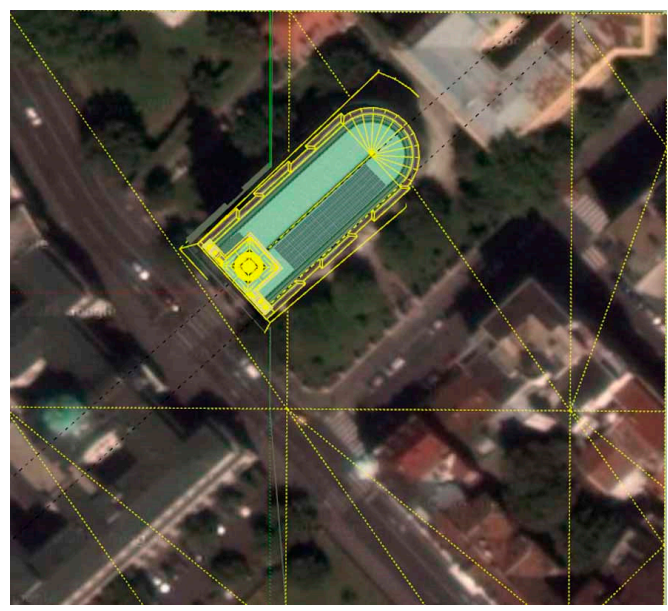

(b)

Figure 13. Installation of PV modules on the rooftop of the Cathedral of St. Michael the Archangel in Belgrade: (a) a model; (b) the base plan (authors and [31]).

A considerable surplus can be perceived in the produced amount of electric power as compared to the power needed for decorative illumination. The necessary amount of power is $42,726.77 \mathrm{kWh}$, while the power produced reaches $151,650 \mathrm{kWh}$. The perceived surplus of $108,923.23 \mathrm{kWh}$ can be used for other purposes within the sacred complex (Table 4 and Figure 14). 
Table 4. Comparative review of monthly and annual power production for different options of PV modules installation and electric power consumption for illuminating the Belgrade Cathedral.

\begin{tabular}{ccccc}
\hline & Option 1 & Option 2 & $\begin{array}{c}\text { Electric Power } \\
\text { Consumption }\end{array}$ & Surplus/Shortage \\
\hline 1 & 5715 & 6141 & 4655.60 & 1059.4 \\
2 & 8627 & 9023 & 3967.05 & 4659.95 \\
3 & 12,478 & 12,735 & 3750.75 & 8727.25 \\
4 & 15,800 & 15,625 & 3194.34 & $12,605.66$ \\
5 & 19,478 & 18,883 & 2792.85 & $16,685.15$ \\
6 & 19,578 & 18,710 & 2289.69 & $17,288.31$ \\
7 & 20,030 & 19,271 & 2554.40 & $17,475.6$ \\
8 & 18,731 & 18,394 & 2950.44 & $15,780.56$ \\
9 & 12,389 & 12,416 & 3368.10 & 9020.9 \\
10 & 9794 & 10,108 & 4042.24 & 5751.76 \\
11 & 5218 & 5485 & 4346.60 & 871.4 \\
12 & 3812 & 4076 & 4814.74 & -1002.74 \\
Total & $\mathbf{1 5 1 , 6 5 0}$ & $\mathbf{1 5 0 , 8 9 4}$ & $\mathbf{4 2 , 7 2 6 . 7 7}$ & $\mathbf{1 0 8 , 9 2 3 . 2 3}$ \\
\hline
\end{tabular}

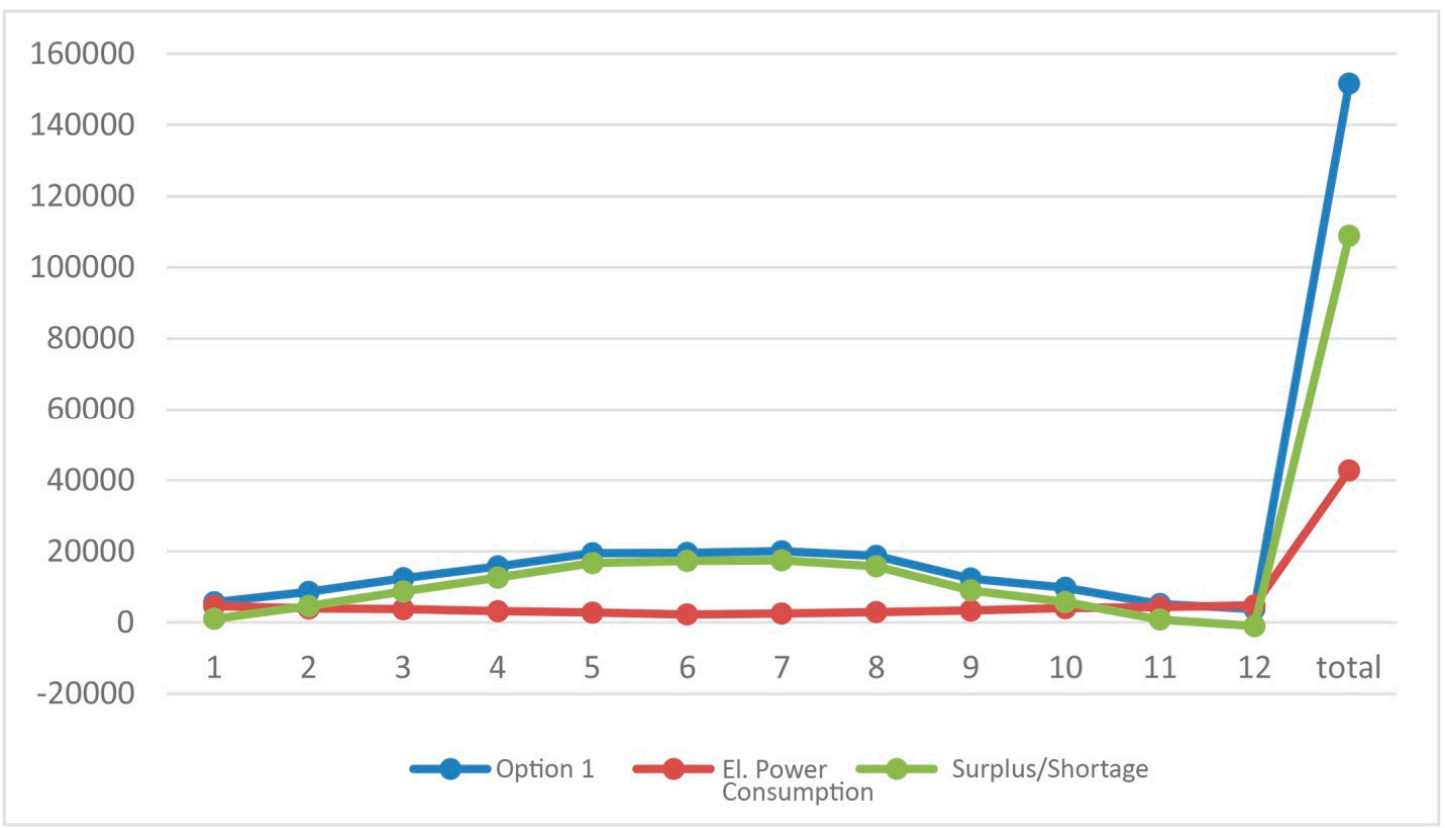

Figure 14. Spread sheet of electric power production to electric power consumption ratio.

The benefits of the application of PV systems are not just in reducing electricity bills; its effects are more far-reaching, since they contribute to the preservation of the environment through a reduction in $\mathrm{CO}_{2}$ emissions, thus contributing to public health. However, the initial investment can pose a problem. That is the very reason Serbia should rely on the experience of the countries that have adopted incentives for the application of the renewable energy sources and with it the production of electric power by means of PV systems. Aldo Orioli et al. [32] presented the incentives Italy introduced in order to increase the production of electric power through PV systems. By comparative analysis of the two mechanisms (feet-in tariff and tax loans), they estimated the efficiency of energy strategies through investments and their economic cost-effectiveness. The strategy of incentivizing the application of PV systems is essential for broadening the awareness of the public in Serbia on the significance of renewable energy sources, thus enabling their application. 


\section{Discussion and Conclusions}

This paper is aimed at examining the possibilities of PV technology application in public lighting of protected sacred architecture (Figure 15). By applying PV structures in such sites, the issue of their lighting can be successfully and sustainably solved. The motive behind this research lies in the need for the theoretical and critical resolution of sustainability issues in heritage areas. There was no intention here to present the economic analysis or to justify the application of PV modules. Integrated PV systems raise the public awareness of renewable energy sources and environmental protection. The optimum orientation and positioning of PV modules can contribute to their increased energy efficiency. Evidently, different inclinations of photovoltaic modules yield different results of the total annual production of electric power.

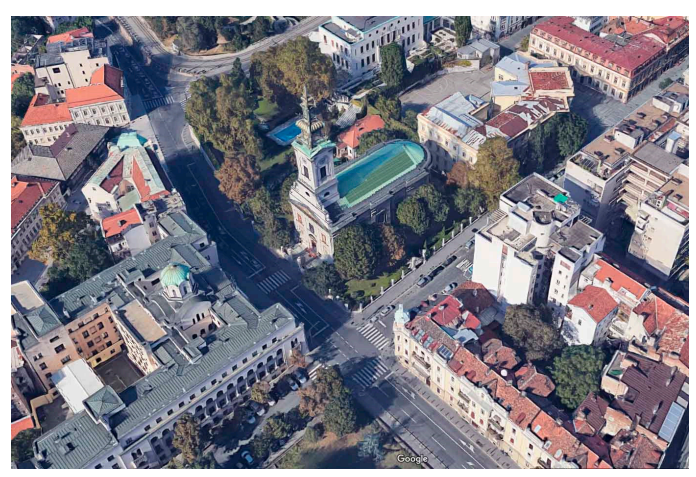

(a)

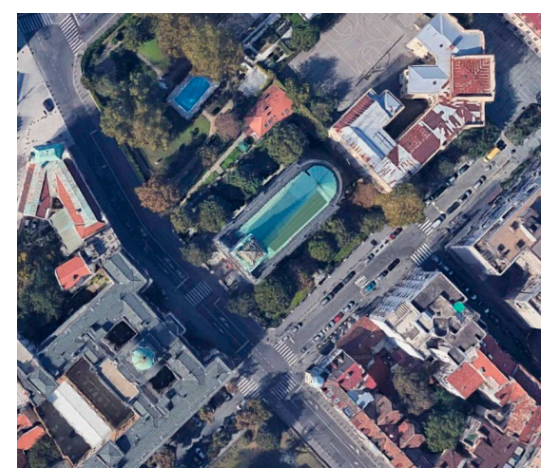

(b)

Figure 15. Installation of PV panels on the rooftop of the Cathedral of St. Michael the Archangel in heritage area of Belgrade called Kosančićev venac. (a) 3D view; (b) Top view (Google maps and authors).

Application of PV structures solves the problem of illumination in protected urban areas powered from renewable energy sources. Renewable energy systems are gaining importance in the overall form and appearance of structures in which they are applied. The present research includes the specificities of form-related and programmatic interventions on sacred buildings, analyzing the form-related effects of photovoltaic panels on heritage structures as well as their contribution to the use of renewable energy sources.

Designing such elements and conceptualizing the use of renewable energy sources in this way aims at the improvement and super integration of the basic human needs for energy, and are seen as an entirely novel approach in protecting and revitalizing architectural structures. A modern approach to the protection and revitalization of cultural monuments allows the use of elements of certain characteristics and contain qualitative values and indicators of the energy potential of such units. The application of PV modules should not degrade the heritage value and dignity of cultural monuments in any way.

Bearing in mind that in Serbia the PV systems still have not been used on sacred buildings, certain guidelines on using solar power and the application of PV systems on churches can be drawn from foreign experience. From the aspect of heritage protection, installation of PV panels on heritage churches commands the following:

- $\quad$ PV panels should be installed as mountable and demountable panels on sub-structures, irrespective of a building, so that they can be removed without impact on the protected facility [5],

- to enable reversibility, the return of a building in the shape as before the intervention and the PV system installation,

- to determine the optimum position of PV panels for each sacred building so as not to disrupt its visual appearance or to diminish its aesthetic and historic values;

- to preserve the appearance and stylistic authenticity of the heritage church. 
In line with all the above-mentioned, state-of-the-art technologies and materials enable that PV panels be produced in the color of the base they are installed on, or that they be integrated in it (e.g., in roof covering-solar roof tiles, slates, wood shingles). Using renewable energy sources will soon become a necessity in every facility, regardless of whether there is a need for it, so the task would be to find the most suitable and the most efficient ways and places for their installation. Most certainly heritage buildings, that need to be passed on to future generations intact, and with preserved aesthetic and stylistic characteristics, would pose a particular challenge. In order to use renewable energy sources in Serbia, it is necessary to:

- educate the society on the efficiency and the use of renewable energy sources;

- pass legal acts (laws, rulebooks and standards) on using renewable energy sources;

- promote the use of renewable energy sources by means of state subsidies.

In the end, it can be concluded that the application of photovoltaic systems in sacred heritage buildings in Serbia would principally serve as a tool to educate and increase the awareness of the whole society on the importance and possibilities of their use, all with the agenda of reducing the commercial energy consumption and $\mathrm{CO}_{2}$ environmental emissions in order to secure ecological and economic sustainability. The relevance of this research is reflected in finding and interpreting a new model which, in a specific way, affects the overall optimization of the roof. It can be concluded, based on these results, that the analyzed model entirely meets the assumed energy potential of PV panels. The contribution of renewable energy sources to the electric power production by means of PV panels is estimated by the comparative analysis of the proposed methods of PV panels installation. The task of further research would be to analyze the combination of specific variants of PV modules that would meet the architectural and visual aspects of PV modules application on heritage areas. The analysis clearly showed that the installation of PV systems in sacred heritage buildings would contribute to the ecological quality of such spaces without impairing their visual identity.

Author Contributions: Conceptualization, B.S., A.U. and M.J.; methodology, B.S. and A.U.; software, B.S.; validation, B.S., A.U. and M.J.; formal analysis, B.S. and A.U.; investigation, B.S., A.U. and M.J.; data curation, A.U. and M.J.; writing-original draft preparation, B.S. and A.U.; writing-review and editing, B.S. and A.U.; visualization, B.S., A.U. and M.J.; funding acquisition, B.S. All authors have read and agreed to the published version of the manuscript.

Funding: This paper was produced as part of the project themed "Studying climate change and its influence on the environment: impacts, adaptation and mitigation" (43007) financed by the Ministry of Education, Science and Technological Development of the Republic of Serbia.

Acknowledgments: We would like to extend out thanks to the Ministry of Education, Science and Technological Development of the Republic of Serbia and the University of Belgrade, the Faculty of Architecture for funding this work.

Conflicts of Interest: The authors declare no conflict of interest.

\section{References}

1. Sheila, J.H.; Alicen, K. Renewable Energy Applications for Existing Buildings. Preprint. Presented at the 48th AiCARR International Conference, Baveno-Lago Maggiore, Italy, 22-23 September 2011; Available online: https://pdfs.semanticscholar.org/e4f4/4986df383623c4ec191338a54871bf4ca00f.pdf (accessed on 15 October 2019).

2. World Commission on Environment and Development (WCED). Our Common Future; Oxford University Press: Oxford, UK, 1987.

3. Smita, K.; Kenneth, I.; Marco, P.; Arman, H. Potential and Impact of Incorporating Roof Photovoltaic to Enhance Environmental Sustainability of Historic English Churches in the United Kingdom. In IOP Conference Series: Earth and Environmental Science; IOP Publishing: Bristol, UK, 2019. [CrossRef]

4. Jovan, N. Revitalizacija Spomenika Kulture; Univerzitet u Beogradu, Arhitektonski Fakultet: Beograd, Serbia, 1986. 
5. Murgul, V.; Vera, M. Solar energy systems in the reconstruction of heritage historical buildings of the northern towns (for example Saint-Petersburg). J. Appl. Eng. Sci. 2014, 12, 121-128. [CrossRef]

6. Slobodan, N. Zaštita Graditeljskog Nasleđa; Univerzitet u Beogradu, Arhitektonski Fakultet: Beograd, Serbia, 1980.

7. Vlada, R.S. Nacionalna strategija održivog korišćenja prirodnih resursa i dobara. Sl. glasnik Rep. Srbije 2012, $33,12$.

8. Cristina, P.L.; Francesco, F. Energy efficiency and renewable solar energy integration in heritage historic buildings. Energy Procedia 2014, 48, 1493-1502.

9. Available online: https://www.mypoweruk.com/gloucester-cathedral-installation/ (accessed on 15 October 2019).

10. Available online: https://www.nationalgeographic.com/news/2013/2/130228-environmental-pope-greenefficiency-vatican-city/ (accessed on 15 October 2019).

11. Budimir, S.; Anđela, D. The use of renewable energy sources in urban protected cultural-historical ambiences. SAJ 2016, 8, 145-165.

12. Željko, Đ.; Dimitrije, K.; Goran, D.; Pavle, D. Generalni Projekat Sa Prethodnom Studijom Izvodljivosti: Fotonaponske Elektrane Nezavisne Snage $300 \mathrm{~kW}$ u Sklopu "Realne Laboratorije Za Elektrane"; Univerzitet u Beogradu, Arhitektonski Fakultet: Beograd, Serbia, 2015.

13. Available online: https://www.energetskiportal.rs/obnovljivi-izvori-energije/energija-sunca/ (accessed on 23 October 2019).

14. Franzitta, V.; Orioli, A.; Di Gangi, A. Assessment of the Usability and Accuracy of the Simplified One-Diode Models for Photovoltaic Modules. Energies 2016, 9, 1019. [CrossRef]

15. Franzitta, V.; Orioli, A.; Di Gangi, A. Assessment of the Usability and Accuracy of Two-Diode Models for Photovoltaic Modules. Energies 2017, 10, 564. [CrossRef]

16. Ingo, H. Gebaudeintegrierte Photovoltaik-Architektonische Integration der Photovoltaik in Die Gebaudehulle; Rudolf Muler: Koln, Germany, 2002; pp. 34-53, 192-193.

17. Probst, M.; Roecker, C. Solar Energy Systems in Architecture_Integration Criteria and Guidelines; International Energy Agency: Paris, France, 2012; pp. 83-104.

18. Available online: https://www.exsolar.co.za/mono-vs-poly-vs-thin-film-panels.html (accessed on 20 October 2019).

19. Cabeza, L.F.; De Gracia, A.; Pisello, A.L. Integration of renewable technologies in historical and heritage buildings: A review. Energy Build. 2018, 177, 96-111. [CrossRef]

20. Cristina, P.L.; Elena, L.; Franco, G. Acceptance of Building Integrated Photovoltaic (BIPV) in Heritage Buildings and Landscapes: Potentials, Barrier and Assessment Criteria. In Proceedings of the Construction Pathology, The Euro-American Congress REHABEND (Rehabilitation Technology and Heritage Management) 2020, Granada, Spain, 24-27 March 2020.

21. Isa, Z.; Pierluigi, B.; Francesco, F.; Erika, S.; Guus, V.; van den Menno, D.; Kostas, S.; Wiep, F. Building Integrated Photovoltaics: Product Overview for Solar Building Skins; Status Report 2017 SUPSI-SEAC, SUPSI; University of Applied Sciences and Arts of Southern Switzerland: Lugano, Switzerland, 2017; Available online: http://www.bipv.ch/images/Report\%202017_SUPSI_SEAC_BIPV.pdf (accessed on 28 January 2020).

22. Irena, S. Saborna Crkva; Zavod Za Zaštitu Spomenika Kulture Grada Beograda: Beograd, Srbija, 2008; pp. 1-6.

23. Available online: https://structurae.net/en/structures/cathedral-church-of-saint-michael-the-archangel (accessed on 25 October 2019).

24. Available online: https://www.saborna-crkva.com/index.php?option=com_content\&task=view\&id=35\& Itemid=48 (accessed on 25 October 2019).

25. Zakon o Kulturnim Dobrima; Službeni Glasnik RS: Beograd, Serbia, 1994; br. 7.

26. Available online: http://www.hidmet.gov.rs/latin/meteorologija/klimatologija_srbije.php (accessed on 23 October 2019).

27. Available online: http://www.hidmet.gov.rs/eng/meteorologija/stanica_sr.php?moss_id=13274 (accessed on 23 October 2019).

28. Available online: http://www.beograd.rs/index.php?lang=cir\&kat=beoinfo\&sub=1191\%3f (accessed on 23 October 2019). 
29. Zoran, N.; Vladimir, Š.; Petar, P. Energy Efficient Power Supply of Autonomous Consumers Using Hybrid (Photovoltaic and Diesel Aggregates). Available online: https:/pdfs.semanticscholar.org/ a93f/32fb48845b488a2428f7fe9609ab09b860a2.pdf?_ga=2.233173150.1238667352.1572447875-312652199. 1570533851 (accessed on 15 October 2019).

30. Available online: https://grist.org/article/2011-06-10-solar-panels-to-match-your-couch/ (accessed on 20 October 2019).

31. Available online: https://3dwarehouse.sketchup.com/model/cfe06bd57ae55049c8c7d2d629e90472/Sabornacrkva-u-Beogradu?hl=ko (accessed on 25 October 2019).

32. Aldo, O.; Vincenzo, F.; Alessandra, D.G.; Ferdinando, F. The Recent Change in the Italian Policies for Photovoltaics: Effects on the Energy Demand Coverage of Grid-Connected PV Systems Installed in Urban Contexts. Energies 2016, 9, 944. [CrossRef]

(C) 2020 by the authors. Licensee MDPI, Basel, Switzerland. This article is an open access article distributed under the terms and conditions of the Creative Commons Attribution (CC BY) license (http://creativecommons.org/licenses/by/4.0/). 